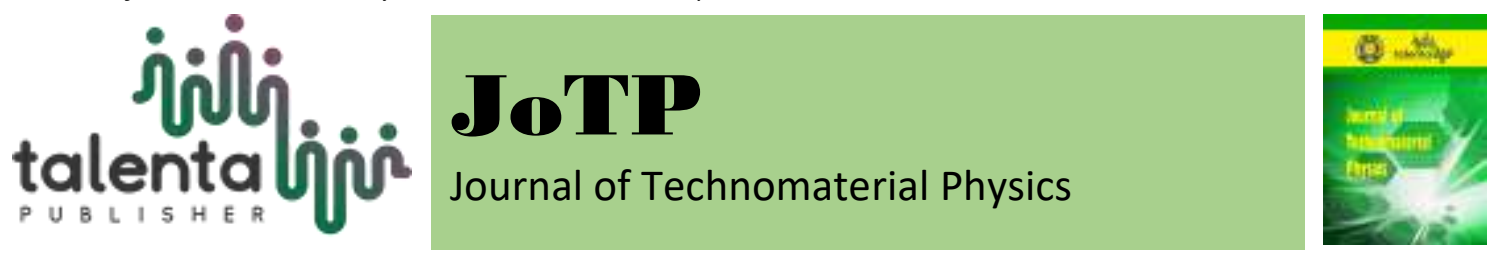

\title{
Difference in the Amount of Voltage between Solid and Liquid Form of Bilimbi Fruit as an Alternative Energy Source
}

\author{
Elisa $^{1}$ and Caca Candra Kirana ${ }^{2}$ \\ ${ }^{1,2}$ Physics Education, Unsyiah, Banda Aceh 23111, Indonesia
}

\begin{abstract}
The present study aimed to discover whether there was a difference in the amount of voltage between liquid bilimbi and fresh bilimbi fruit as an alternative energy source. The research samples were 100 grams of fresh bilimbi and 100 grams of liquid bilimbi. The samples were connected to a multimeter through zinc plate and copper plate using a crocodile clip cable. After connected, the voltage measurement of the bilimbi was carried out five times in order to obtain accurate data. The collected data were averaged, and the difference between the two samples was calculated. The results showed that the average amount of voltage from liquid bilimbi was $0.72 \mathrm{~V}$ while the average amount of voltage from fresh bilimbi was $1.42 \mathrm{~V}$. Thus, the difference between the two forms of bilimbi was $0.7 \mathrm{~V}$. In conclusion, there was a difference in the amount of voltage produced by liquid bilimbi and fresh bilimbi fruit as an alternative energy source in which fresh bilimbi fruit had a higher amount of voltage than the liquid bilimbi.
\end{abstract}

Keyword: The amount of voltage, liquid bilimbi, fresh bilimbi

Received 01 April 2019 | Revised [29 July 2019] | Accepted [31 August 2019]

\section{Introduction}

Human needs for energy keep increasing. The existing energy source, therefore, should be increased to meet human needs for energy [1-3]. One of the most needed energy sources by humans is electricity [4-7]. States that electricity is considered as highly required energy in the modern era. Electricity has an important role in life because it is the main energy source in every activity in households and industries. Furthermore, the rapid growth of population also led to an increase in energy needs which has become a problem for the community because it leads to the high price of electricity and high industrial costs.

Therefore, previous studies have been conducted to find alternative energy sources that can be used as an electrical energy source. One of the previous studies was conducted by [8] examining the relationship between the strength of the electric current and the acidity of oranges and

\footnotetext{
*Corresponding author at: Physics Education, Unsyiah, Banda Aceh 23111, Indonesia

E-mail address: kaslielisa@unsyiah.ac.id
} 
mangoes. The study found that the relationship between the strength of the electric current and the acidity of oranges and mangoes was inversely proportional. In other words, smaller $\mathrm{pH}$ value in the fruit (the mode acidic the fruit) resulted in greater electric current strength. Another study was conducted by [1] regarding the preparation of bio-batteries from durian skin. The findings showed that durian skin waste has the potential to be an environmentally friendly biobatteries in which the voltage generated will be greater if the mixture concentration is added.

In addition, [9] studied the composition of seawater and sea sand which can be used as an alternative source of electrical energy. The study found that there was electrical voltage in the mixture of sea sand and seawater with a certain composition. After measuring using a multimeter, the result showed that a greater mass of seawater resulted in greater voltage produced.

Based on these studies, researchers would like to find another alternative energy source which is useful as a source of electricity by utilizing materials in the environment. One of the materials that can be used as an alternative electrical energy source is Averrhoa bilimbi (locally known as belimbing wuluh). In general, bilimbi is used as sunti acid and as a complement for cooking [10-11]. The abundant amount of bilimbi can be used as a source of electrical energy [12-15].

Previously, [16] has shown that there is energy in Galvanic cells in bilimbi extracts. Galvanic cells are cells that produce electric current consisting of cathode, anode, and electrolyte components. In addition to bilimbi extracts, bilimbi which has not been extracted can also be used as an energy source. However, the difference between the voltage generated by bilimbi fruit and its extracts has not investigated yet.

Based on the description above, the present research aimed to find whether there was a difference in the amount of voltage produced by liquid bilimbi and fresh bilimbi fruit. This study was expected to provide an overview to the community about which form of bilimbi more effective as an alternative electrical energy source was. Therefore, researchers were interested in find out difference in the amount of voltage produced by liquid bilimbi and bilimbi fruit which have not been mashed.

This study aimed to find the difference in the amount of voltage produced by bilimbi extracts and bilimbi fruit which have not been mashed as an alternative energy source.

\section{Materials and Methods}

This research was conducted at the Third Floor of the Physics Laboratory in FKIP Unsyiah on Wednesday, $18^{\text {th }}$ October 2017 . The method in this study was an experimental method in order to find the voltage generated by liquid bilimbi and solid bilimbi. Tools and materials used in the study were liquid bilimbi, fresh bilimbi fruit, multimeter, zinc plate $(\mathrm{Zn})$, copper plate $(\mathrm{Cu})$, crocodile clip cable, scale, and containers. Data of liquid bilimbi was collected by inserting zinc 
$(\mathrm{Zn})$ and copper $(\mathrm{Cu})$ plates on the right and left sides of the container containing the liquid bilimbi. The two plates were connected by a multimeter using crocodile clip cable. The measured voltage in the multimeter was recorded. The measurement was repeated five times. To collect data of solid bilimbi fruit, $100 \mathrm{~g}$ of bilimbi fruits were arranged in a row (7 bilimbi fruits $=100 \mathrm{~g})$. Then, bilimbi fruits were assembled with zinc $(\mathrm{Zn})$ and copper $(\mathrm{Cu})$ plates on both sides of bilimbi so that all fruits were connected as one unit. After that, the zinc and copper plates were attached to the multimeter, and the amount of voltage produced was calculated. The voltage measurement was repeated five times.

\section{Result and Discussion}

\subsection{Research Results}

After the experiment was conducted, the data obtained are as follows:

Table 1. Measurement data on the amount of voltage produced by liquid and solid bilimbi

$$
\text { (mass }=100 \text { grams) }
$$

\begin{tabular}{lllllll}
\hline \multirow{2}{*}{ No } & \multirow{2}{*}{ Name and form of substance } & \multicolumn{5}{c}{ Voltage (Volt) } \\
\cline { 3 - 7 } & & I & II & III & IV & V \\
\hline 1 & Liquid bilimbi & 0.72 & 0.72 & 0.72 & 0.72 & 0.72 \\
2 & Solid bilimbi & 1.43 & 1.41 & 1.41 & 1.42 & 1.44 \\
\hline
\end{tabular}

Source : Physics Laboratory of FKIP, 2017

Once calculated, the average voltage of $100 \mathrm{~g}$ of liquid bilimbi was:

$$
\overline{\mathrm{V}}=\frac{(0.72+0.72+0.72+0.72+0.72)}{5}=0.72 \mathrm{~V}
$$

For $100 \mathrm{~g}$ of solid bilimbi, the average voltage was:

$$
\overline{\mathrm{V}}=\frac{(1.43+1.41+1.41+1.42+1.44)}{5}=1.42 \mathrm{~V}
$$

Thus, the difference in the amount of voltage was:

$$
1.42 \text { volt }-0.72 \text { volt }=0.7 \text { volt } \text {. }
$$

\subsection{Discussion}

Based on the calculation results, the average voltage of the liquid bilimbi was $0.72 \mathrm{~V}$ with a scale limit of $20 \mathrm{~V}$ on the multimeter. On the other hand, the average voltage of the solid bilimbi was $1.42 \mathrm{~V}$ with a scale limit of $20 \mathrm{~V}$ on the multimeter. The results showed a difference in the amount of voltage produced from the two forms of bilimbi. The liquid bilimbi produced a smaller voltage than the solid bilimbi for a mass of $100 \mathrm{~g}$ each. 
The process applied in this study was in accordance with the process of Galvanic cells or voltaic cells in which the cell consists of components in the form of electrodes and electrolytes. If there are two different electrodes placed on the electrolyte, Galvanic cells can produce electrical energy. The electrical energy produced by these chemical reactions arises spontaneously. The electrical energy arises because the two electrodes are placed in the same container and connected to a multimeter aims to calculate the electrical voltage which occurs. The electrons will finally flow through the outer circuit to the cathode and move to a substance in the electrolyte, so the substance that receives electrons will experience reduction. In the electrolyte (inner circuit), the load will be carried by the cation to the cathode and by the anion to the anode. This reaction will occur repeatedly which then generate electrical energy [8].

Based on that process, the process occurs in the present study can be explained. The electrolytes used in this study were liquid bilimbi and fresh bilimbi fruit whereas the electrodes in the reaction were copper and zinc. Copper acted as a cathode which was a place for reduction while zinc acted as an anode which was a place of oxidation. Copper and zinc were placed in a container containing the same electrolyte and were connected to a multimeter. After connected, a chemical reaction occurred spontaneously. This is because electrons flew towards the copper and moved towards the electrolyte so that the substance experienced reduction. In the electrolyte, the load was transported by cation to copper and by anion to zinc. The repeated chemical reaction would eventually lead to electrical energy. It can be seen in the multimeter which shows the value of $1.42 \mathrm{~V}$ when the electrolyte was bilimbi fruit and $0.72 \mathrm{~V}$ when the electrolyte was liquid bilimbi. This voltage can be used as an alternative energy source applied to various equipment which is useful for human needs.

In a previous study by [16] about Galvanic cells from bilimbi, the results indicated that a Galvanic cell system can produce electric voltage and current of $0.72 \mathrm{~V}$ and $0.29 \mathrm{~mA}$ for liquid bilimbi, respectively. The same results were also found in the present research. The present research was carried out to determine the amount of voltage in fresh bilimbi fruit. The findings showed that fresh bilimbi fruit produced higher voltage with $1.42 \mathrm{~V}$ than liquid bilimbi with $0.72 \mathrm{~V}$. The amount of voltage produced by fresh bilimbi fruit is two times greater than that of liquid bilimbi.

The difference in the amount of voltage that occurs is due to the distance of solid bilimbi substance molecules is denser than that of the liquid bilimbi. It means that smaller distance ${ }^{\circledR}$ will result in greater electric force (F) produced, and vice versa (Coulomb's Law).

The utilization of alternative energy source derived from bilimbi fruit is useful for our country which experiences an energy crisis, especially electricity. As our country has abundant natural resources, the existing natural resources should be used optimally to help in the crisis of the country's energy sources [17-20]. Therefore, alternative energy should be utilized optimally. 


\section{Conclusion}

Based on the research results and discussion, it can be concluded that there was a difference in the amount of voltage produced by the solid and liquid form of bilimbi fruit. The distance between molecules is smaller in the solid bilimbi than that of the liquid bilimbi so that the force of electricity produced is different.

\section{References}

[1] Khairiah and R. Destini, "Analisis Kelistrikan Pasta Elektrolit Limbah Kulit Durian (Durio zibethinus) Sebagai Bio Baterai," in Prosiding Seminar Nasional Pendidikan FKIP UNTIRTA, pp. 41-44, Banten, 2017.

[2] H. Krugmann and J. Goldemberg, "The Energy Cost of Satisfying Basic Human Needs." Technological Forecasting and Social Change, vol. 24, no. 1, pp 45-60, 1983.

[3] D. Robinson, "Some Trends and Research Needs in Energy and Comfort Prediction", in Comfort and Energy Use in Building, 27-30 April 2006, Windsor, United Kingdom, No. CONF. 2006.

[4] T. T. Gultom, "Pemenuhan Sumber Tenaga Listrik di Indonesia," Jurnal Ilmiah Research Sains, vol. 3, no. 1, pp. 130-138, 2017.

[5] H. Lund and W. Kempton. "Integration of Renewable Energy into The Transport and Electricity Sectors Through V2G." Energy Policy, vol. 36, no. 9, pp. 3578-3587, 2008.

[6] C-W. Shyu, "Ensuring Access to Electricity and Minimum Basic Electricity Needs As A Goal For The Post-MDG Development Agenda After 2015," Energy for Sustainable Development, vol. 19, pp. 29-38, 2014.

[7] S. Tully, "The Human Right to Access Electricity." The Electricity Journal, vol. 19, no. 3 , pp. 30-39, 2006.

[8] H. Kholida and Pujayanto, "Hubungan Kuat Arus Listrik dengan Keasaman Buah Jeruk dan Mangga.," in Prosiding Seminar Nasional Fisika dan Pendidikan Fisika (SNPF) Ke-6, vol. 6, no. 1, pp. 42-46, 2015.

[9] O. P. Prastuti, "Pengaruh Komposisi Air Laut dan Pasir Laut Sebagai Sumber Energi Listrik," Jurnal Teknik Kimia dan Lingkungan, vol. 1, no. 1, pp. 35-41, 2017.

[10] M. Muzaifa, "Perubahan Karakteristik Fisik Belimbing Wuluh selama Fermentasi Asam Sunti," Jurnal Teknologi dan Industri Pertanian Indonesia, vol. 5, no. 2, pp. 7-11, 2013.

[11] A. Lennox and J. Ragoonath, "Carambola and Bilimbi," Fruits, vol. 45, no. 5, pp. 497-501, 1990.

[12] S. Rahmawati and Agnesstacia. "Analysis of Factors That Affect The Potential of Star Fruit (Averhoa blimbi) and Cactus (Gymnocalycium hossei) Extracts as Alternative Battery." In 4th International Conference on Mathematics and Natural Sciences (ICMNS 2012) AIP Conference Proceedings, vol. 1589, no. 1, pp. 516-521. American Institute of Physics, 2014.

[13] T. A. Fadlly, Fajriani, and T. Harmawan. "Characteristic I-V of $\mathrm{Cu} / \mathrm{Cu}_{2} \mathrm{O}$ Solar Cells with Belimbing Wuluh (Averrhoa bilimbi L.) Electrolyte Using Sun Simulator." Jurnal Neutrino: Jurnal Fisika dan Aplikasinya, vol. 11, no. 1, pp. 6-10, 2018.

[14] N. H. Kamarulzaman, H. Salleh, M. S. M. Ghazali, S. M. Ghazali and Z. Ahmad, "The Electrical Conductivity and Energy Band Gap of 'Bunga Belimbing Buluh' $/ \mathrm{TiO}_{2}$ Nanocrystals as Hybrid Solar Cell," In International Laser Technology and Optics Symposium (ILATOS 2017) IOP Conf. Series: Journal of Physics: Conf. Series, vol. 1027, no. 1. IOP Publishing, 2018.

[15] R. S. R. Isaac, G. Sakthivel and C. Murthy. "Green Synthesis of Gold and Silver Nanoparticles Using Averrhoa bilimbi Fruit Extract." Journal of Nanotechnology, vol. 2013, pp. 1-6, 2013.

[16] S. Suryaningsih, "Belimbing Wuluh (Averra bilimbi) Sebagai Sumber Energi Dalam Sel 
Galvani," Jurnal Pendidikan Fisika dan Aplikasinya (JPFA), vol. 06, no. 01, pp. 11-17, 2016.

[17] Atina, "Tegangan dan Kuat Arus Listrik dari Sifat Asam Buah," Jurnal Sainsmatika, vol. 12, no. 2, pp. 28-42, 2015.

[18] S. Yongping and Y. Chusheng, "Abundant Natural Resources and Industry Structure Distortion: Influence Mechanism and Multi-Dimensional Measure," Nanjing Journal of Social Sciences, vol. 6, pp. 1-8, 2012.

[19] F. Gérard and F. Ruf. "Agriculture in Crisis: People, Commodities and Natural Resources in Indonesia 1996-2001 1 $1^{\text {st }}$ edition," London: Routledge, 2013.

[20] R. Dutu, "Making The Most of Natural Resources in Indonesia." OECD Economics Department Working Papers, vol. 1, no. 1236, pp. 1-43, 2015. 